\title{
Biological characteristics of Trichogramma pretiosum Riley, 1879 (Hymenoptera: Trichogrammatidae) under temperature stress by successive generations
}

\author{
Luis Moreira de Araujo Juniora®, Hugo Bolsoni Zago ${ }^{\circledR} \bullet$, Alixelhe Pacheco Damascena ${ }^{\mathrm{a}^{*} \bullet}$, \\ Luana Viana Fariab®, Aléxia Gonçalves Pereirac®, Fernando Zanotti Madalonb®, \\ José Romário de Carvalhod®, Dirceu Pratissolie® \\ a Programa de Pós-Graduação em Produção Vegetal, Universidade Federal do Espírito Santo, \\ Alegre, 29500-000, Espírito Santo, Brasil. \\ b Programa de Pós-Graduação em Entomologia, Universidade Federal de São Paulo Luiz de Queiroz, \\ Piracicaba, 13418-900, São Paulo, Brasil. \\ c Programa de Pós-Graduação em Genética e Melhoramento, Universidade Federal do Espírito Santo, \\ Alegre, 29500-000, Espírito Santo, Brasil.*xellydamascena@hotmail.com \\ d Secretaria de Educação do Estado do Espírito Santo, Jerônimo Monteiro, 29550-000, Espírito Santo, Brasil. \\ e Programa de Pós-Graduação em Agronomia, Universidade Federal do Espírito Santo, \\ Alegre, 29500-000, Espírito Santo, Brasil.
}

Received: October, 13, 2020 / Accepted: May 11, 2021 / Published online: May 27, 2021

\begin{abstract}
The objective of this study was to evaluate the biological characteristics of Trichogramma pretiosum (Riley 1879) under room temperature and temperature stress by successive generations. The evaluation was carried out in split-plot in the time. The temperature $\left(25^{\circ} \mathrm{C}\right.$ - room temperature and $33{ }^{\circ} \mathrm{C}$ - temperature stress) was the Factor 1 and the Generations $(\mathrm{n}=15)$ were the Factor 2. The biological characteristics evaluated were: longevity; posterior tibia length; number of parasitized eggs; emergence; egg-adult period; sexual ratio and deformed individuals. The increase in temperature, from the first generations of $T$ pretiosum, caused an influence in all observed variables. However, for the emergence and sex ratio variables, there was no significant difference between heat stress and control (room temperature) as of the 14th generation, which suggests an adaptability of the species. This adaptability may imply obtaining more aggressive natural enemies in relation to their host (insect pest) and consequently in the greater efficiency of biological control.
\end{abstract}

Keywords: Acclimation; biological control; climatic factors; egg parasitoid.

\section{Características biológicas de Trichogramma pretiosum Riley, 1879 (Hymenoptera: Trichogrammatidae) sob estresse de temperatura por gerações sucessivas}

\section{Resumo}

O objetivo deste estudo foi avaliar as características biológicas de Trichogramma pretiosum (Riley 1879) submetido a temperatura ambiente e estresse térmico por sucessivas gerações. A avaliação foi realizada em parcelas subdividida no tempo. A Temperatura $\left(25^{\circ} \mathrm{C}\right.$ - temperatura Ambiente e $33^{\circ} \mathrm{C}$ - estresse térmico) foi o Fator 1 e as gerações $(\mathrm{n}=15)$ foram o Fator 2. As características biológicas avaliadas foram: longevidade; comprimento da tíbia posterior; número de ovos parasitados; emergência; período ovo-adulto; razão sexual e indivíduos deformados. O aumento da temperatura, provocou, desde as primeiras gerações de $T$ pretiosum, influência em todas as variáveis observadas. Entretanto, para as variáveis emergência e a razão sexual, não houve diferença significativa entre o stress térmico e o controle (temperatura ambiente) a partir da 14 geração , o que sugere-se uma adaptalibidade da espécie. Esssa adaptabilidade podem implicar na obtenção de inimigos naturais mais agressivos em relação ao seu hospedeiro (inseto praga) e consequentemente na maior eficiência do controle biológico.

Palavras-chave: Aclimatação; controle biológico; fatores climáticos; parasitoide de ovo.

\section{Introduction}

The set of mutualistic biotic interactions of natural enemies is as relevant as any other factor in agricultural productivity, because it regulates deleterious actions in the plant, caused by herbivorous organisms (De Bach, 1964; Van Den Bosh, Messenger, \& Gutierrez, 1982). In this context, the egg 
parasitoids of the genus Trichogramma Westwood, 1833 (Hymenoptera Trichogrammatidae) are widely used as natural enemies in biological control of pests, either by inundative or inoculative release of the parasitoid in the area of cultivation, where they are exposed to climatic factors.

The effect of global warming in recent decades has led to an increase in the frequency and intensity of high temperatures, which tend to increase further and to affect communities of natural occurrence of Trichogramma spp., in the world's major agricultural areas (Wu, Hoffmann, \& Thomson, 2016). The species Trichogramma pretiosum Riley, 1879 (Hymenoptera: Trichogrammatidae) was considered the most polyphagous and distributed in Brazil (Querino, Mendes, Costa, \& Zucchi, 2017). In the Espírito Santo state, the presence of wild $T$. pretiosum was observed in regions of different altitudes, across different temperature conditions (Pratissoli et al., 2003).

Among the climatic factors, the temperature is the one that exerts more influence on the parasitoids, being one of the main regulators of insects metabolism (Angilletta, Niewiarowski, \& Navas, 2002). In laboratory conditions, the constant temperature of $25^{\circ} \mathrm{C}$ was shown to be the most favorable for the maintenance of $T$. pretiosum activities, but when subjected to extremes between $28{ }^{\circ} \mathrm{C}$ and $33{ }^{\circ} \mathrm{C}$ there was a significant reduction in longevity, parasitism, emergence, developmental cycle and sexual ratio (Bueno, Parra, \& Freitas Bueno, 2012; Carvalho et al., 2017; Oliveira, de Oliveira, Breda, França, \& Duarte, 2017).

The acclimation consists of physiological adjustments, due to exposure to a climatic stressor (Moyes \& Schulte, 2010). The possible acclimation of $T$. pretiosum at high temperatures might be relevant to the understanding of the mechanism of tolerance of the insect, in biological control of agricultural pests under adverse conditions. Therefore, the objective of this work was to evaluate the biological characteristics of $T$. pretiosum under room temperature and temperature stress by successive generations.

\section{Materials and Methods}

The $T$. pretiosum was originally obtained from an area cultivated with corn (S 2052'28.75" W 41 $\left.{ }^{\circ} 29^{\prime} 1.65^{\prime \prime}\right)$ at Alegre, Espírito Santo, Brazil in September 2016. For this work, the $T$. pretiosum was raised on Anagasta kuehniella (Zeller, 1879) eggs in laboratory.

\section{Experiment}

The essay consisted of the evaluation of the biological characteristics of $T$. pretiosum exposed to $25 \pm 1{ }^{\circ} \mathrm{C}$ (room temperature) and $33 \pm 1{ }^{\circ} \mathrm{C}$ (temperature stress) by 15 generations, in regulated chambers (Eletrolab, serial number: 080336, potency: $280 \mathrm{~W}$, voltage: $220 \mathrm{~V}$, model: EL202) to $70 \pm 10 \% \mathrm{RH}$ and photophase of $14 \mathrm{~h}$ (L:D). The temperature $33 \pm 1{ }^{\circ} \mathrm{C}$ was chosen for being the upper limit for the development of $T$. pretiosum (Oliveira et al., 2017). The parental generation (G0) was composed of females from the ninth generation of the population established in the standard laboratory condition. Therefore, it was used only for the preimaginal conditioning of females due to changes in the environment.

\section{Biological characteristics analysis}

In order to standardize the samples in each generation, the 20 females with larger size, without deformation and emerged up to six hours old were individualized in glass tubes of $8.5 \mathrm{~cm} \times 2.5 \mathrm{~cm}$, closed with PVC plastic film, contained by a droplet of honey, to feed the parasitoid, and a carton with 40 eggs of A. kuehniella of $24 \mathrm{~h}$, offered daily. The individualization of the 20 females in the following generations occurred only in the cartons of the first day.

In the females, the longevity (days) and the posterior tibial length $(\mathrm{mm})$ were evaluated. In the posture, the cumulative number and the emergence rate of parasitized eggs were evaluated. In the progenies, the duration of the development cycle (egg-adult period), the sexual ratio and the percentage of deformed individuals were evaluated.

The longevity of the females was determined by daily observations, from emergence to death. The measurement of the posterior tibia was performed in a micrometric eyepiece. The cumulative number of parasitized eggs was obtained by counting and summing all days of parasitism. The emergency percentage was calculated based on the number of eggs that had exit orifice in relation to the total number of parasitized eggs.

In the evaluation of the egg-adult period, the observations were made daily, always at the same time. The sex ratio was calculated by dividing the number of females by the total number of individuals (males + females) and the dimorphism determined by the antennas (Bowen \& Stern, 1966). The percentage of deformed individuals was calculated based on the number of individuals that presented some type of deformation in relation to the total number of individuals emerged.

The biological characteristics were evaluated in split-plot in the time. The temperature $\left(25^{\circ} \mathrm{C}\right.$ and $\left.33{ }^{\circ} \mathrm{C}\right)$ was the Factor 1 and the generation (15 generation) was the Factor $r$ 2 . The data were submitted to analysis of variance. The averages were compared to the level of $5 \%$ probability in the test of Scott Knott due to the high number of levels of Factor 2. The statistical analyzes were performed in the $R$ Development Core Team (2019) progam.

\section{Results and Discussion}

In general, all variables showed better values for the $\mathrm{T}$ pretiosum generations exposed to room temperature, except for the last generations (generations 13 to 15) in the emergence variable, where there were no significant differences between the temperatures (Tables 1 and 2).

Within the room temperature, the values of all generations in all variables were statistically equal. Within the Temperature $33{ }^{\circ} \mathrm{C}$, there was a gradual increase in the values of all variables over the generations.

Heat stress caused a high presence of individual deformations in all generations. This difference in values between the temperatures confirms how stressful the Temperature $33^{\circ} \mathrm{C}$ was for the $T$. pretiosum. 
Table 1. Longevity, posterior tibia length, number and viability (emergence) of the parasitized eggs by Trichogramma pretiosum females in successive generations at $25^{\circ} \mathrm{C}$ and $33^{\circ} \mathrm{C}$.

\begin{tabular}{|c|c|c|c|c|c|c|c|c|}
\hline \multirow[t]{2}{*}{ G } & \multicolumn{2}{|c|}{ Longevity (Days) } & \multicolumn{2}{|c|}{ Posterior tibia length $(\mathrm{mm})$} & \multicolumn{2}{|c|}{ Number of parasitized eggs } & \multicolumn{2}{|c|}{ Emergence (\%) } \\
\hline & $25^{\circ} \mathrm{C}$ & $33^{\circ} \mathrm{C}$ & $25^{\circ} \mathrm{C}$ & $33^{\circ} \mathrm{C}$ & $25^{\circ} \mathrm{C}$ & $33{ }^{\circ} \mathrm{C}$ & $25^{\circ} \mathrm{C}$ & $33^{\circ} \mathrm{C}$ \\
\hline 1 & $.8 \pm 0.79^{a}$ & $1.3 \pm 0.36^{\mathrm{d}}$ & $.1322 \pm 0.0007^{\mathrm{a}}$ & $0.1140 \pm 0.0030^{\mathrm{e}}$ & $197.85 \pm 25.04^{\mathrm{a}}$ & $38.35 \pm 13.02^{\mathrm{d}}$ & $80.54 \pm 2.87^{a}$ & $45.08 \pm 2.82^{\mathrm{g}}$ \\
\hline 2 & $.8 \pm 0.89^{a}$ & $1.6 \pm 0.48^{\mathrm{d}}$ & $.1323 \pm 0.0005^{\mathrm{a}}$ & $0.1179 \pm 0.00$ & $87.75 \pm 47.78^{a}$ & $42.10 \pm 15.99^{d}$ & $0.66 \pm 3.21^{\mathrm{a}}$ & $3.12^{\mathrm{g}}$ \\
\hline 3 & $.9 \pm 1.21^{\mathrm{a}}$ & $2.3 \pm 0.47^{\mathrm{c}}$ & $1323 \pm 0.0005^{\mathrm{a}}$ & $0.1184 \pm 0.00$ & $9.45 \pm 55.61^{\mathrm{a}}$ & $39.50 \pm 11.90^{\mathrm{d}}$ & $.74 \pm 2.56^{\mathrm{a}}$ & $.28^{\mathrm{g}}$ \\
\hline 4 & $.6 \pm 1.47^{\mathrm{a}}$ & $1.9 \pm 0.48^{\mathrm{d}}$ & $.1325 \pm 0.0005^{\mathrm{a}}$ & $0.1242 \pm 0.0033^{\mathrm{c}}$ & $20.10 \pm 44.95^{\mathrm{a}}$ & $62.15 \pm 15.65^{\mathrm{c}}$ & $79.22 \pm 4.98^{\mathrm{a}}$ & 45.30 \\
\hline 5 & $.1 \pm 1.05^{\mathrm{a}}$ & $2.6 \pm 0.60^{c}$ & $0.1323 \pm 0.0005^{\mathrm{a}}$ & $0.1240 \pm 0.0029^{c}$ & $06.75 \pm 30.10^{a}$ & $58.25 \pm 17.89^{c}$ & $.05 \pm 2.17^{\mathrm{a}}$ & 45.20 \\
\hline 6 & $0 \pm 1.08^{\mathrm{a}}$ & $2.7 \pm 0$ & $1324 \pm 0$. & 0.1249 & $04.70 \pm 29.75^{\mathrm{a}}$ & $70.40 \pm 12.63^{c}$ & $07 \pm 2.24^{\mathrm{a}}$ & 52.60 \\
\hline 7 & $7.7 \pm 1.03^{\mathrm{a}}$ & $3.5 \pm 0$ & $23 \pm 0$ & 0.1 & $6.65 \pm 3$ & $67.25 \pm 13.18^{c}$ & $08 \pm 2.59^{\mathrm{a}}$ & 56.61 \\
\hline 8 & $7.9 \pm 0.72^{\mathrm{a}}$ & $3.5 \pm 0.50^{\mathrm{b}}$ & $0.1324 \pm 0.0004^{\mathrm{a}}$ & $0.1246 \pm 0.0$ & $202.35 \pm 25.59^{\mathrm{a}}$ & 68.65 & $79.80 \pm 2.96^{\mathrm{a}}$ & $71.19 \pm 2.92^{\mathrm{d}}$ \\
\hline 9 & $.9 \pm 0.76^{\mathrm{a}}$ & $3.2 \pm 0.48^{\mathrm{b}}$ & $.1324 \pm 0.0004^{\mathrm{a}}$ & $0.1258 \pm 0.0030^{\mathrm{c}}$ & $06.70 \pm 22.78^{a}$ & $70.80 \pm 14.08^{c}$ & $79.09 \pm 3.41^{\mathrm{a}}$ & $3.14^{\mathrm{c}}$ \\
\hline 10 & $4 \pm 1.57^{\mathrm{a}}$ & $3.0 \pm 0.40^{c}$ & $.1325 \pm 0.0005^{\mathrm{a}}$ & $0.1274 \pm 0.00$ & $192.95 \pm 62.06^{a}$ & $81.95 \pm 16.68^{c}$ & $79.45 \pm 2.45^{\mathrm{a}}$ & $75.97 \pm 2.96^{b}$ \\
\hline 11 & $.2 \pm 1.93^{\mathrm{a}}$ & $4.2 \pm 0.51^{\mathrm{a}}$ & $.1324 \pm 0.0$ & $0.1287 \pm 0.0$ & $177.45 \pm 64.44^{\mathrm{a}}$ & $88.95 \pm 15.39^{b}$ & $80.19 \pm 2.43^{\mathrm{a}}$ & 74.61 \\
\hline 12 & $5 \pm 1.85^{\mathrm{a}}$ & $4.4 \pm 0.40^{\mathrm{a}}$ & $0.1325 \pm 0.0004^{\mathrm{a}}$ & $0.1282 \pm 0$. & $188.25 \pm 61.70^{\mathrm{a}}$ & $95.65 \pm 17.03^{b}$ & $79.65 \pm 2.08^{a}$ & $74.32 \pm 2.93^{c}$ \\
\hline 13 & $8.7 \pm 1.87^{\mathrm{a}}$ & $4.6 \pm 0.43^{a}$ & $0.1326 \pm 0.0004^{\mathrm{a}}$ & $0.1302 \pm 0.0034^{\mathrm{a}}$ & $186.95 \pm 64.22^{\mathrm{a}}$ & $111.80 \pm 13.45^{\mathrm{a}}$ & $80.14 \pm 2.68^{a}$ & $77.00 \pm 3.37^{b}$ \\
\hline 14 & $8 \pm 3.32^{\mathrm{a}}$ & $4.8 \pm 0.41^{\mathrm{a}}$ & $0.1323 \pm 0.0005^{\mathrm{a}}$ & 0.1304 & $176.70 \pm 69.05^{a}$ & $=11.26^{\mathrm{a}}$ & $79.46 \pm 7.13^{a}$ & $78.70 \pm 2.09^{a}$ \\
\hline 15 & $3 \pm 1.07^{\mathrm{a}}$ & $4.6 \pm 0.43^{a}$ & $0.1325 \pm 0.0004^{\mathrm{a}}$ & $0.1308 \pm 0.0034^{\mathrm{a}}$ & $211.35 \pm 22.84^{\mathrm{a}}$ & $125.30 \pm 11.34^{\mathrm{a}}$ & $80.55 \pm 2.87^{a}$ & $78.91 \pm 2.14^{\mathrm{a}}$ \\
\hline
\end{tabular}

However, it was observed that T. pretiosum showed better values in all variables throughout its generations. Although these values did not exceed the values reported by $\mathrm{T}$. pretiosum exposed to room temperature and the number of deformities was $53 \%$ lower in generation 7, reducing from 71 to $81 \%$ in the last generations (11 to 15$)$. This tendency suggests that the species demonstrates the evolutionary and adaptive potential to this thermal stress.

The temperature at which insects are exposed directly influences the rate of development. Oliveira et al. (2017) found that the longevity of $T$. pretiosum on eggs of Neoleucinodes elegantalis Guen., 1854 (Lepidoptera: Pyralidae) was reduced from, approximately, 5 days at $25^{\circ} \mathrm{C}$ to 1 days at 33 ${ }^{\circ} \mathrm{C}$. This last value was similar to the first generation at 33 ${ }^{\circ} \mathrm{C}$ of this research, which was $1.33 \pm 0.36$ days. Also in the study by Oliveira et al (2017) there was also a reduction in the values of parasitism, emergence, adult egg period and sexual ratio, when the temperature ranged from $25^{\circ} \mathrm{C}$ to 33 ${ }^{\circ} \mathrm{C}$. Similar tendency were also observed in other studies, regardless of the host (Carvalho et al., 2017; Milanez, Carvalho, Lima, \& Pratissoli, 2018).

Table 2. Duration of the biological cycle (egg-adult period), sexual ratio and percentage of deformed individuals of Trichogramma pretiosum females in successive generations (G) at $25{ }^{\circ} \mathrm{C}$ and $33{ }^{\circ} \mathrm{C}$.

\begin{tabular}{ccc|cc|cc}
\hline $\mathrm{G}$ & \multicolumn{2}{c|}{ Sexual ratio } & \multicolumn{2}{c|}{ Egg-adult period (Days) } & \multicolumn{2}{c}{ Number of parasitized eggs } \\
\cline { 2 - 7 } & $25^{\circ} \mathrm{C}$ & $33^{\circ} \mathrm{C}$ & $25^{\circ} \mathrm{C}$ & $33^{\circ} \mathrm{C}$ & $25^{\circ} \mathrm{C}$ & $33^{\circ} \mathrm{C}$ \\
\hline 1 & $0.77 \pm 0.04^{\mathrm{a}}$ & $0.61 \pm 0.04^{\mathrm{e}}$ & $9.90 \pm 0.31^{\mathrm{a} *}$ & $6.30 \pm 0.57^{\mathrm{c}}$ & $1.78 \pm 0.44^{\mathrm{a}}$ & $20.28 \pm 1.93^{\mathrm{a}}$ \\
2 & $0.78 \pm 0.03^{\mathrm{a}}$ & $0.64 \pm 0.04^{\mathrm{d}}$ & $9.92 \pm 0.28^{\mathrm{a}}$ & $6.50 \pm 0.61^{\mathrm{c}}$ & $1.83 \pm 0.52^{\mathrm{a}}$ & $14.63 \pm 1.60^{\mathrm{c}}$ \\
3 & $0.78 \pm 0.04^{\mathrm{a}}$ & $0.63 \pm 0.04^{\mathrm{e}}$ & $9.95 \pm 0.22^{\mathrm{a}}$ & $6.50 \pm 0.61^{\mathrm{c}}$ & $1.95 \pm 0.86^{\mathrm{a}}$ & $16.24 \pm 2.22^{\mathrm{b}}$ \\
4 & $0.80 \pm 0.04^{\mathrm{a}}$ & $0.65 \pm 0.03^{\mathrm{d}}$ & $10.00 \pm 0.00^{\mathrm{a}}$ & $6.50 \pm 0.51^{\mathrm{c}}$ & $1.89 \pm 0.40^{\mathrm{a}}$ & $15.86 \pm 2.17^{\mathrm{b}}$ \\
5 & $0.79 \pm 0.03^{\mathrm{a}}$ & $0.64 \pm 0.04^{\mathrm{d}}$ & $9.95 \pm 0.22^{\mathrm{a}}$ & $6.75 \pm 0.55^{\mathrm{b}}$ & $1.83 \pm 0.56^{\mathrm{a}}$ & $13.30 \pm 1.91^{\mathrm{d}}$ \\
6 & $0.78 \pm 0.03^{\mathrm{a}}$ & $0.65 \pm 0.05^{\mathrm{d}}$ & $9.95 \pm 0.22^{\mathrm{a}}$ & $6.80 \pm 0.52^{\mathrm{b}}$ & $1.67 \pm 0.79^{\mathrm{a}}$ & $11.78 \pm 1.47^{\mathrm{e}}$ \\
7 & $0.78 \pm 0.03^{\mathrm{a}}$ & $0.64 \pm 0.04^{\mathrm{d}}$ & $9.80 \pm 0.41^{\mathrm{a}}$ & $6.60 \pm 0.50^{\mathrm{c}}$ & $1.71 \pm 0.43^{\mathrm{a}}$ & $9.62 \pm 1.43^{\mathrm{f}}$ \\
8 & $0.78 \pm 0.03^{\mathrm{a}}$ & $0.61 \pm 0.05^{\mathrm{d}}$ & $9.95 \pm 0.22^{\mathrm{a}}$ & $6.75 \pm 0.55^{\mathrm{b}}$ & $1.80 \pm 0.30^{\mathrm{a}}$ & $8.18 \pm 1.54^{\mathrm{g}}$ \\
9 & $0.78 \pm 0.04^{\mathrm{a}}$ & $0.66 \pm 0.05^{\mathrm{d}}$ & $9.95 \pm 0.22^{\mathrm{a}}$ & $7.45 \pm 0.60^{\mathrm{a}}$ & $1.84 \pm 0.28^{\mathrm{a}}$ & $7.55 \pm 1.80^{\mathrm{g}}$ \\
10 & $0.79 \pm 0.02^{\mathrm{a}}$ & $0.67 \pm 0.03^{\mathrm{d}}$ & $10.00 \pm 0.32^{\mathrm{a}}$ & $7.55 \pm 0.51^{\mathrm{a}}$ & $1.89 \pm 0.84^{\mathrm{a}}$ & $7.98 \pm 1.69^{\mathrm{g}}$ \\
11 & $0.77 \pm 0.08^{\mathrm{a}}$ & $0.70 \pm 0.03^{\mathrm{c}}$ & $10.00 \pm 0.46^{\mathrm{a}}$ & $7.65 \pm 0.59^{\mathrm{a}}$ & $1.88 \pm 1.38^{\mathrm{a}}$ & $5.88 \pm 1.70^{\mathrm{h}}$ \\
12 & $0.79 \pm 0.03^{\mathrm{a}}$ & $0.70 \pm 0.04^{\mathrm{c}}$ & $10.10 \pm 0.31^{\mathrm{a}}$ & $7.70 \pm 0.57^{\mathrm{a}}$ & $1.46 \pm 0.85^{\mathrm{a}}$ & $4.21 \pm 1.38^{\mathrm{i}}$ \\
13 & $0.79 \pm 0.05^{\mathrm{a}}$ & $0.74 \pm 0.03^{\mathrm{b}}$ & $10.10 \pm 0.31^{\mathrm{a}}$ & $7.75 \pm 0.55^{\mathrm{a}}$ & $1.57 \pm 0.97^{\mathrm{a}}$ & $4.25 \pm 1.16^{\mathrm{i}}$ \\
14 & $0.76 \pm 0.06^{\mathrm{a}}$ & $0.77 \pm 0.03^{\mathrm{a}}$ & $10.00 \pm 0.32^{\mathrm{a}}$ & $7.80 \pm 0.52^{\mathrm{a}}$ & $1.96 \pm 0.66^{\mathrm{a}}$ & $4.25 \pm 1.20^{\mathrm{i}}$ \\
15 & $0.80 \pm 0.03^{\mathrm{a}}$ & $0.78 \pm 0.03^{\mathrm{a}}$ & $10.10 \pm 0.55^{\mathrm{a}}$ & $7.85 \pm 0.59^{\mathrm{a}}$ & $1.78 \pm 0.58^{\mathrm{a}}$ & $3.92 \pm 1.28^{\mathrm{i}}$ \\
\hline
\end{tabular}

* Averages followed by the same lowercase in the column, do not differ significantly at $5 \%$ probability by the Scott Knott test.

However, despite the temperature stress condition of $T$. pretiosum females in this study, it was observed that the longevity, tibial length, number of parasitized eggs and adult emergence rate increased. The size of the females of Trichogramma spp., based on the length of the tibia, has been used as an index of performance and quality of the biological control agent, due to the significant relationship between the size of the individual and biological fitness (Kazmer \& Luck, 1995). Therefore, it is possible that the growth of longevity, parasitism and egg viability values occurred due to the increase of the T. pretiosum size.

Probably, the exhaustion of thermal capacity has compromised the development of individuals, as has occurred in organisms of different species (Owen \& Stern, 
1966; Kingsolver \& Huey, 2008; Zuo, Moses, West, Hou, \& rown, 2012; Nielsen \& Papaj, 2015). Therefore, certainly for this reason, in the early generations more males of $T$. pretiosum were produced due to the need to select genotypes that were more tolerant to thermal stressors, which led to a tendency to regulate the duration of the biological cycle and reduce the number of deformed individuals.

The biological characteristics of $T$. pretiosum, under temperature stress, tends to evolve over generations. These data can be used for future acclimatization and / or genetic improvement tests for $T$. pretiosum, to be used in places whose release has been impracticable due to the occurrence of high temperatures.

\section{Conclusion}

T. pretiosum showed negative effects on its development under heat stress. However, over fifteen generations, individual deformities were significantly reduced and all values for longevity; posterior tibia length; number of parasitized eggs; emergence; egg-adult period; sexual ratio improved.

This improvement of $T$. pretiosum under temperature stress for successive generations may suggest that the species demonstrates an adaptive potential to this thermal stress.

The adaptive evolution of the $T$. pretiosum may imply greater aggressiveness of the parasitoid in relation to its host. Then, as an environmental impact, greater efficiency in biological pest control is expected, but without major risks to nature, because it is a specific action organism, that is, they parasitize only certain groups of insects and do not leave toxic residues in the environment.

\section{References}

Angilletta Jr, M.J., Niewiarowski, P.H., \& Navas, C.A. (2002). The evolution of thermal physiology in ectotherms. Journal of thermal iology, 27(4), 249-268. doi: 10.1016/S0306-4565(01)00094-8

Owen, W.R., \& Stern, V.M. (1966). Effect of temperature on the production of males and sexual mosaics in a uniparental race of Trichogramma semifumatum (Hymenoptera: Trichogrammatidae). Annals of the Entomological Society of America, 59(4), 823-834. doi: 10.1093/aesa/59.4.823

Bueno, R.C.O.F., Parra, J.R.P., \& de Freitas ueno, A. (2012). Trichogramma pretiosum parasitism of Pseudoplusia includens and Anticarsia gemmatalis eggs at different temperatures. iological Control, 60(2), 154162. doi: 10.1016/j.biocontrol.2011.11.005

Carvalho, G.D.S., Silva, L.., Reis, S.S., Veras, M.S., Carneiro, E., Almeida, M.L.D.S., \& Lopes, G.N. (2017). iological parameters and thermal requirements of Trichogramma pretiosum reared on Helicoverpa armigera eggs. Pesquisa agropecuária brasileira, 52(11), 961-968. doi: 10.1590/s0100-204x2017001100001

De Bach, P. (1964). iological control of insect pests and weeds. iological control of insect pests and weeds.

Kazmer, D.J., \& Luck, R.F. (1995). Field tests of the size-fitness hypothesis in the egg parasitoid Trichogramma pretiosum. Ecology, 76(2), 412-425. doi: $10.2307 / 1941200$

Kingsolver, J.G., \& Huey, R.. (2008). Size, temperature, and fitness: three rules. Evolutionary Ecology Research, 10(2), 251-268.

Milanez, A.M., Carvalho, J.R.D., Lima, V.L.S., \& Pratissoli, D. (2018). Functional response of Trichogramma pretiosum on Trichoplusia ni eggs at different temperatures and egg densities. Pesquisa Agropecuária rasileira, 53(5), 641-645. doi: 0100-204x2018000500013

Moyes, C., \& Schulte, P. (2010). Sistemas Respiratórios. Princípios de Fisiologia Animal $2^{a} e d$. Porto Alegre: Artmed, 412-467.

Nielsen, M.E., \& Papaj, D.R. (2015). Effects of developmental change in body size on ectotherm body temperature and behavioral thermoregulation: caterpillars in a heat-stressed environment. Oecologia, 177(1), 171179. doi: $10.1007 / \mathrm{s} 00442-014-3123-3$

Oliveira, C.M., Oliveira, J.V., Breda, M.O., França, S.M., \& Duarte, .L.R. (2017). iological parameters and thermal requirements of Trichogramma pretiosum for the management of the tomato fruit borer (Lepidoptera: Crambidae) in tomatoes. Crop Protection, 99, 39-44. doi: 10.1016/j.cropro.2017.04.005

Pratissoli, D., Fornazier, M.J., Holtz, A.M., Gonçalves, J.R., Chioramital, A.., \& Zago, H.. (2003). Ocorrência de Trichogramma pretiosum em áreas comerciais de tomate, no Espírito Santo, em regiões de diferentes altitudes. Horticultura rasileira, 21(1), 73-76. doi: 10.1590/S010205362003000100015

Querino, R.., Mendes, J.V., Costa, V.A., \& Zucchi, R.A. (2017). New species, notes and new records of Trichogramma (Hymenoptera: Trichogrammatidae) in razil. Zootaxa,4232(1), 137-143. doi: 10.11646/zootaxa.4232.1.11

$\mathrm{R}$ development core team (2019). R: A language and environment for statistical computing, R Foundation for Statistical Computing, Vienna. Available in: https://www.R-project.org/

Van den osch, R., Messenger, P.S., \& Gutierrez, A.P (1982). An Introduction to biological control. Plenum Press, New York.

Wu, L.H., Hoffmann, A.A., \& Thomson, L.J. (2016). Potential impact of climate change on parasitism efficiency of egg parasitoids: a metaanalysis of Trichogramma under variable climate conditions. Agriculture, Ecosystems \& Environment, 231, 143-155. doi: 10.1016/j.agee.2016.06.028

Zuo, W., Moses, M.E., West, G.., Hou, C., \& rown, J.H. (2012). A general model for effects of temperature on ectotherm ontogenetic growth and development. Proceedings of the Royal Society : iological Sciences, 279(1734), 1840-1846. doi: 10.1098/rspb.2011.2000

License: Creative Commons CC Y 4.0

This article was published with open access for distribution under the terms of the Creative Commons Attribution License, which allows unrestricted use, distribution, and reproduction in any medium, provided the original work is properly cited. 